\title{
Nutritional, physicochemical and anatomical evaluation of creole corn varieties from the region of the Costa Chica of Guerrero
}

\author{
Victor Manuel RIVERA-CASTRO ${ }^{1}$, María Dolores MUY-RANGEL ${ }^{2}$, Roberto GUTIÉRREZ-DORADO 3 , \\ José Luis ESCOBAR-ÁLVAREZ ${ }^{4}$, Elías HERNÁNDEZ-CASTRO ${ }^{5}$, José Luis VALENZUELA-LAGARDA ${ }^{1 *}$ (1D)
}

\begin{abstract}
Corn (Zea mays) is the most consumed cereal in México, so it is necessary to know the nutritional and anatomical quality of the grains, which have been the main conservation and consumption criteria of the prehispanic peoples. This practice has allowed to preserve varieties of Creole corn, however, due to the lack of knowledge of these characteristics the cultivation of these maize has been reduced, presenting a high risk of disappearing. The objective was to determine the physical, nutritive and functional quality of four varieties of creole corn: Purple-Olotillo, Dos-Puntas, Toro and Olotillo. Toro presented the highest values of width and thickness $(10.79$ and $7.71 \mathrm{~mm})$. The Toro showed better values of Endosperm and Pericarp $(84.25 \%$ and $4.01 \%)$, Dos-Puntas and Olotillo showed higher values of Germ (10.75\%) and Pericarp (6.2\%), respectively. The Toro had a higher content of Carbohydrates and Proteins (74.47 and 10.61\%). In WSI, the best value was obtained by Dos-Puntas (11.91\%) and WAI the Olotillo ( $245.56 \mathrm{~g} \mathrm{H}_{2} \mathrm{O} / \mathrm{g}$ sample). It is concluded that the Toro has better nutritional content and larger and weight grains, while the Olotillo presented the highest values of WAI, it can confer better technological properties for food processing.
\end{abstract}

Keywords: creole corn; grain anatomy; water absorption index; water solubility index.

Practical Application: Creole corn has stopped growing, so the preservation of its germplasm is in danger, due to its pigmentation and genetic nature, this type of maize has competitive nutritional contents with hybrid maize. The color, solubility index and water absorption are indicators of the functionality of the flours for the food industry, however, studies of the nutritional and/or functional quality of the corn have not been carried out. This research provides information that can contribute to the use of creole corn from the State of Guerrero in the food industry.

\section{Introduction}

Corn is a grass belonging to the family of the Poaceae (Wellhausen et al., 1951), its name comes from mahís that means what sustains life (Colín, 2000), it is the basic cereal of food in México (Hernández-Casillas \& Esquivel-Esquivel, 2004); this country has the highest per capita consumption in the world with a value of $336.6 \mathrm{~kg}$ (Sistema de Información Agroalimentaria y Pesquera, 2018). México is considered the center of origin, domestication and diversification, there are a great variety of creole maize throughout the country (Fernández-Suárez et al., 2013); this diversity that is a product of selection and reproduction of the best grains (Kato et al., 2009), practice that goes back to about 10 thousand years (Colín, 2000). This cereal occupies a planting area of more than 7.5 million hectares, $80 \%$ of this area is worked by small producers who mainly produce it for selfconsumption (México, 2018). This system represents the main source of national production, with more than $50 \%$ of national production (Fernández-Suárez et al., 2013). This production practice has allowed the conservation, diversification and improvement of native breeds, all according to the needs of rural populations (Turrent-Fernández et al., 2012). However, the producers of the

Costa Chica of Guerrero have gradually replaced this type of maize with hybrid maize, which can be attributed to the fact that in terms of yield the improved varieties have proven to be, by far, superior to the native ones, even when the native varieties have a better adaptation to the edapho-climatic conditions of each rural area (Guillén-Pérez et al., 2002; Turrent-Fernández et al., 2012). For a long time the selection of the native races focused on the yield of dry matter (Turrent-Fernández et al., 2012), nowadays more in-depth aspects are taken regarding the selection of the best grains (Magdaleno-Hernández et al., 2016), focusing on physical factors (empirically), such as: grain length, width and thickness (Magdaleno-Hernández et al., 2016). Currently, when it is sought to preserve the best varieties of corn, not only is it limited to the physical part, taking into account nutritional factors (Fernández-Suárez et al., 2013) and possible uses (Aguayo-Rojas et al., 2012). The physical quality of a grain is measured by a great variety of factors, the main ones being length, width, thickness, weight of a thousand seeds (WTS), hectolitre weight $(\mathrm{HW})$ and some related to its anatomical structure (Pérez-Mendoza et al., 2006). The structure of the corn grain is 
divided into Pericarp, Endosperm, Germ and Pedicel, of these is the endosperm that has the highest weight percentage in the grain, and is mainly formed by starch submerged in a protein matrix (Revilla et al., 2008), being the starch granules between 5 - $30 \mu \mathrm{m}$ (Agama-Acevedo et al., 2004); the pericarp is the external part of the grain formed in a $77.7 \%$ fiber, which has a thickness of between 60 to $80 \mu \mathrm{m}$ (Muñoz-Hernández et al., 1999); the germ has the function of a store of nutrients that allow the activation and initiation of germination (Granito \& Guerra, 1995). The pedicel is the anchor structure to the cob, which allows the exchange of liquids from the pedicel to the pericarp (Aguilar-Castillo et al., 2006). The anatomical structure is closely related to the nutritional quality of the grain, this is because it is in the germ where most of the lipids are located, in the endosperm, the carbohydrates and proteins and in the pericarp, together with the fiber endosperm (Paredes-López et al., 2009). The WTS is related to the percentage of endosperm, because it represents between $80-83 \%$ of the total weight of the grain (Domínguez Pacheco et al., 2010), the HW is a measure of the ease of obtaining flour, since the higher the HW, the higher the flour yield (López et al., 2005). For all this, it is necessary to know the physical quality, and with it the nutritional, of Creole breeds from different regions of México, this study is based on four native varieties from the Costa Chica in the State of Guerrero.

\section{Materials and Methods}

\subsection{Biological material}

The seeds were collected in the months of August-September of the year 2017, in the region of the Costa Chica de Guerrero, the Dos-Puntas variety, was collected from the municipality of Florencio Villareal ( $16^{\circ} 44^{\prime} 0.7$ “ $\left.\mathrm{N}, 99^{\circ} 06^{\prime} 53.6^{\prime \prime} \mathrm{W}\right)$, the variety Toro and Purple-olotillo in the municipality of Ayutla de los Libres $\left(16^{\circ} 57^{\prime} 26.0^{\prime \prime} \mathrm{N}, 99^{\circ} 07^{\prime} 46.3^{\prime \prime} \mathrm{W}\right)$ and the variety Olotillo in the municipality of Cuautepec ( $16^{\circ} 44^{\prime} 46.6^{\prime \prime} \mathrm{N}, 99^{\circ} 00^{\prime} 49.6^{\prime}$ ' W).

\subsection{Seed quality}

Seed Size

Fifty viable seeds were selected per repetition (3 repetitions), using a digital vernier (UltraTech $\mathrm{H}-7352$ ), the length, width and thickness of each seed was measured, the results were reported as the average of each attribute (Burak \& Broccoli, 2004).

\section{Thousand Kernel Weight (TKW)}

One thousand viable seeds were selected per repetition (3 repetitions) which were weighed on a digital balance VeLab-500, the result was calculated as the average of the obtained data (Salinas-Moreno \& Aguilar-Modesto, 2010).

\section{Hectolytic Weight (HW)}

It was determined by means of the test tube method, in which a graduated cylinder of $100 \mathrm{ml}$ and 100 seeds was used, this was done with 10 repetitions, in which the sample weight and the displaced volume were taken; the WH was calculated with the following Equation 1 (Pérez-Mendoza et al., 2006) and expressed in $\mathrm{Kg} \mathrm{hL}^{-1}$ :
$H W=\frac{\text { displaced volume }}{\text { sample weight }} \times 100$

\subsection{Seed Anatomy}

Fifty viable seeds were selected, which were left to soak for 24 hours, later with the help of a scalpel, the endosperm, pericarp, pedicel and germ were separated after drying in a forced air oven, once dried they were weighed and the results were calculated with the following Equation 2 (Figueroa-Cárdenas et al., 2013):

$\%$ parte $=\frac{\text { weight of the anatomical part }}{\text { weight seed }} \times 100$

\subsection{Nutritional value of corn}

\section{Moisture}

In a constant weight crucible, $2 \mathrm{~g}$ of sample was added and dried in a forced air oven for 16 hours, then removed from the oven and placed in a desiccator until it reached room temperature, the crucible was weighed and the Moisture was determined with the following Equation 3:

$\%$ Moisture $=\frac{\text { initial weight }- \text { final weight }}{\text { initial weight }} \times 100$

Ash

The crucible used in the humidity analysis was placed in a muffle at $550^{\circ} \mathrm{C}$ for 24 hours, after which time the crucible was placed in a desiccator until it reached an ambient temperature, then it was weighed and the ash content was determined with the following Equation 4:

$\%$ ash $=\frac{\text { initial weight }- \text { final weight }}{\text { initial } \text { weight }} \times 100$

\section{Determination of total lipids (ether extract)}

A Buchi brand extractor was used, on a \# 41 watman filter paper, two grams of sample were placed and introduced into an extraction thimble, in previously tared extraction vessels the thimble and $75 \mathrm{ml}$ of petroleum ether were placed, once the vessels in the equipment the existing extraction program was run for four hours, after that period began with the solvent recovery stage, the vessels were placed in a stove to complete the evaporation of the ether, the amount of fat was calculated with the following Equation 5:

$\%$ total lipids $=\frac{\text { initial weight }- \text { final weight }}{\text { initial weight }} \times 100$

\section{Protein}

A microKjeldahl flask with $200 \mathrm{mg}$ of sample $(0.2 \mathrm{~g})$ was placed in a Buchi brand microKjeldahl, $1.5 \mathrm{~g}$ of catalyst mixture and $5 \mathrm{ml}$ of sulfuric acid were added, the flasks were placed in a Buchi Brand Digester at $50{ }^{\circ} \mathrm{C}$ for $40 \mathrm{~min}$ (until obtaining a blue-green coloration), later the flasks were placed in the equipment and this will determine with the help of a pre-established software the amount of protein present. 


\section{Fiber dietary}

In flasks for $40 \mathrm{ml}$ fiber, $1 \mathrm{~g}$ of sample was placed (two flasks per sample) and an enzymatic digestion was performed using a-amylase, protease and amyloglucosidase, which were given the ideal conditions and allowed to act for $30 \mathrm{~min}$. After the digestion period, $300 \mathrm{ml}$ of $96 \%$ ethanol was added and they were allowed to stand for 12 hours to precipitate the solids, after which time the solids were recovered with the help of a filter crucible which was placed $1 \mathrm{~g}$ of celite and left to constant weight, washes were made to the flask with the help of $80 \%$ ethanol, then the crucibles were dried in an oven and the final weight of each crucible was recorded, a crucible was taken to determine proteins and another to determine ashes and was calculated the percentage of fiber by weight difference, using the equation Equation 6 (Grossi et al., 2015).

$\%$ fiber dietary $=\frac{\text { waste weight }-(\text { ash }+ \text { protein })}{\text { sample weigh }} \times 100$

\subsection{Color of corn meal}

Analysis color was determined using a handheld tristimulus colorimeter (Chroma Meter - CR-400, Konica Minolta) calibrated with a white standard tile. A CIE standard illuminant D65 was used to determine the CIELab Cartesian coordinates: $\mathrm{L}^{*}, \mathrm{a}^{*}$ and $b^{\star} . L^{\star}$ denotes lightness or brightness, ranging from zero (black) to 100 (white), $\mathrm{a}^{\star}$ and $\mathrm{b}^{\star}$ are the opposing color coordinates, with $\mathrm{a}^{\star}$ ranging from -60 (green) to +60 (red) and $b^{\star}$ ranging from -60 (blue) to +60 (yellow) (Guiné \& Barroca, 2014).

\subsection{Water solubility index and water absorption index}

They were performed in triplicate according to the procedures described by Anderson et al. (1969), with some modifications. $2.5 \mathrm{~g}(\mathrm{dw})$ of seed meal were weighed, placed in a $50 \mathrm{ml}$ polypropylene tube previously tared, the samples were dissolved in $30 \mathrm{ml}$ of distilled water at room temperature, covered and vigorously stirred 1 minute, and placed in a thermoguider (Precision mark) at a temperature of $30^{\circ} \mathrm{C}$ with constant stirring tray at $70 \mathrm{rpm}$, for 30 minutes. Subsequently, the tubes were centrifuged (Sorvall
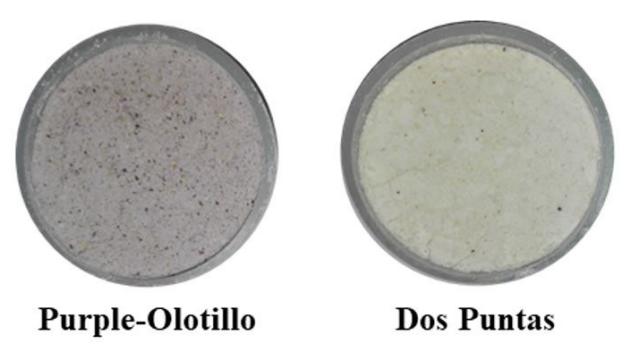

Dos Puntas

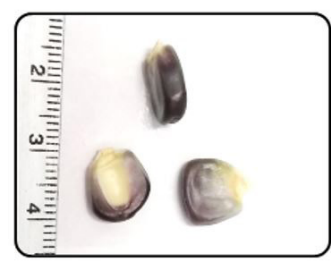

Purple-Olotillo

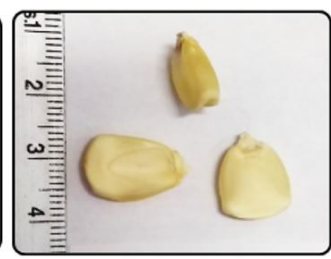

Dos Puntas

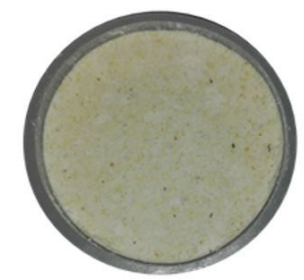

Toro

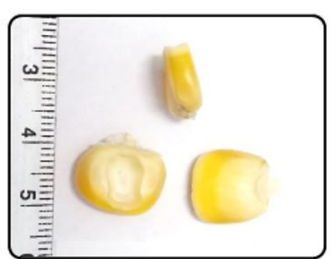

Toro
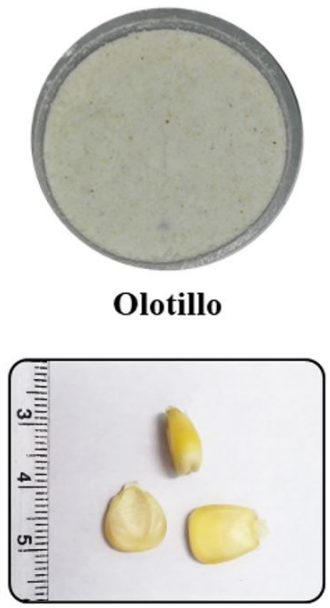

Olotillo

Figure 1. Seed and flour creole corn. 
Table 1. Nutritional content (\%), WSI and WAI.

\begin{tabular}{ccccccccc}
\hline Variety & Carbohydrates & Moisture & Ash & Protein & Lipids & Dietary fiber & WSI & WAI \\
\hline Purple-Olotillo & $72.55 \pm 1.12^{\mathrm{a} *}$ & $7.24 \pm 0.03^{\mathrm{c}}$ & $1.42 \pm 0.02^{\mathrm{b}}$ & $9.02 \pm 0.19^{\mathrm{c}}$ & $3.97 \pm 0.51^{\mathrm{a}}$ & $7.06 \pm 2.15^{\mathrm{b}}$ & $8.07 \pm 0.76^{\mathrm{a}, \mathrm{b}}$ & $234.34 \pm 5.43^{\mathrm{c}}$ \\
Dos-Puntas & $65.86 \pm 0.66^{\mathrm{b}}$ & $5.86 \pm 0.07^{\mathrm{d}}$ & $1.55 \pm 0.02^{\mathrm{a}}$ & $9.02 \pm 0.19^{\mathrm{c}}$ & $4.23 \pm 0.05^{\mathrm{a}}$ & $11.91 \pm 1.16^{\mathrm{a}}$ & $9.92 \pm 1.55^{\mathrm{a}}$ & $231.03 \pm 10.02^{\mathrm{b}, \mathrm{c}}$ \\
Toro & $74.47 \pm 0.81^{\mathrm{a}}$ & $7.72 \pm 0.28^{\mathrm{b}}$ & $1.27 \pm 0.002^{\mathrm{c}}$ & $10.61 \pm 0.03^{\mathrm{a}}$ & $3.73 \pm 0.86^{\mathrm{a}}$ & $1.72 \pm 0.06^{\mathrm{c}}$ & $6.60 \pm 0.83^{\mathrm{b}}$ & $242.10 \pm 1.72^{\mathrm{b}}$ \\
Olotillo & $62.54 \pm 1.84^{\mathrm{c}}$ & $8.09 \pm 0.07^{\mathrm{a}}$ & $1.39 \pm 0.01^{\mathrm{b}}$ & $10.39 \pm 0.08^{\mathrm{b}}$ & $4.51 \pm 0.07^{\mathrm{a}}$ & $13.84 \pm 2.52^{\mathrm{a}}$ & $7.88 \pm 0.61^{\mathrm{a}, \mathrm{b}}$ & $245.56 \pm 1.01^{\mathrm{a}}$ \\
\hline
\end{tabular}

Note: ${ }^{\star}$ Different letters in each row indicate significant difference $(\alpha=0.05)$.

between the ranges of 10.44 to $12.37 \mathrm{~mm}, 8.21$ to $10.79 \mathrm{~mm}$ and 3.92 to $7.71 \mathrm{~mm}$, respectively, which resemble what was obtained by Mauricio-Sánchez et al. (2004), in which it reports means of $11.5 \mathrm{~mm}, 9.0 \mathrm{~mm}$ and $1.2 \mathrm{~mm}$, respectively.

The greatest value for length was presented by the Olotillo variety $(12.37 \mathrm{~mm})$, while the thickness and width was greater in the Toro variety $(7.71$ and $10.79 \mathrm{~mm}$, respectively), the smallest width $(8.68 \mathrm{~mm})$ and less thickness $(3.99 \mathrm{~mm})$. ), was presented by the variety Dos puntas and Olotillo respectively. NavarroGarza et al. (2012) studied creole varieties from the municipality of Tecoanapa in Guerrero, reporting ranges of 9.4 to $9.8 \mathrm{~mm}$ in length, 9.5 to $9.8 \mathrm{~mm}$ in width and $4.5 \mathrm{~mm}$ thickness of local race grains (Palmeño and Olotillo).

Figueroa-Cárdenas et al. (2013) reported on beads of mixed races values of $11.4 \mathrm{~mm}$ for length, $9.0 \mathrm{~mm}$ for width and $4.9 \mathrm{~mm}$ for thickness of grains, the values represented in Table 1 oscillate between what reported by the author, being the variety Toro which has a greater thickness $(7.71 \mathrm{~mm})$; this author reports a weight of one thousand grains (TKG) of $306.7 \mathrm{~g}$, the samples that were analyzed are below this average, can be attributed to the edaphoclimatic differences of each zone.

Regarding the HW, no statistical difference was found, although the variety with the highest value was Olotillo (79.98 $\left.\mathrm{Kg} \mathrm{hL}^{-1}\right)$ and the Morado variety $\left(75.73 \mathrm{Kg} \mathrm{hL}^{-1}\right.$ ) had the lowest value. The $\mathrm{HW}$ is an indirect measure of the hardness of the grain, according to Serna-Saldivar \& Carrillo (2019) the maize to elaborate corn flakes for breakfast must not exceed a $\mathrm{HW}$ of $76 \mathrm{Kg} \mathrm{hL}^{-1}$, of the varieties evaluated the purple it has a value below the established maximum and can be used in the processing of flakes for cereal.

It is observed that the variety with greater the TKW was the Purple-Olotillo (143.11 g); this, in turn, reflects that this variety presents the best values of pericarp and germ, as well as a high HW. The TKW reflects in an indirect way the weight of the endosperm, but this may vary according to the quality of it.

\subsection{Seed anatomy}

Purple-Olotillo and Toro varieties have the best endosperm results (84.25\% for both); the endosperm is composed of starch granules embedded in a protein matrix (Serna-Saldivar, 2010). The cell walls consist of non-starch polysaccharides ( $\beta$-glucan and arabinoxylan), proteins and phenolic acids (Agama-Acevedo et al., 2013). This agrees with that reported by Domínguez-Pacheco et al. (2010) who points out that in mature and dry grains the endosperm represents $83 \%$, the germ $11 \%$, the pericarp $5 \%$ of the total weight of the grain and the pedicel the rest. The corn kernel has two types of endosperm: floury and corneous endosperm, the floury endosperm contains little compacted starch granules that surround the central fissure, while the corneous endosperm has more compact and small starch granules towards the periphery (Serna-Saldivar, 2010).

The Olotillo variety had the highest value in Pericarpio $(6.20 \%)$ and the Purple-Olotillo variety has the lowest value $(4.35 \%)$, the pericarp is also known as "shell", because it is a layer that covers and protects the grain mature, subdivided into epidermis, mesocarp, crossed cells, tubular cells and seed coat, these structures are composed of tubular structures that allow the passage of nutrients from the coppice to the seed (Wolf et al., 1952; Muñoz-Hernández et al., 1999).

Of the four varieties, the one with the highest germ percentage is Dos-Puntas (10.75\%) as well as the Toro variety $(6.40 \%)$ has the lowest percentage of germ; The germ is considered a rich source of fat (White \& Weber, 2003; Paredes-López et al., 2009), besides being a rich source of minerals (78\%), this may be due to the fact that these allow a fast emergence of the seedling (Agama-Acevedo et al., 2013), phosphorus is the main mineral present in it, released by the phytase enzyme when the embryo grows (Agama-Acevedo et al., 2013; Serna-Saldivar, 2010).

The Toro variety presents the largest Pedicel among the four varieties $(4.01 \%)$ and of this variety Olotillo contains the lowest value $(2.41 \%)$, this component of the seed is responsible for supplying nutrients to the germ, through the endosperm besides being responsible for sustaining, composed of cells in the form of stars, arranged in a spongy structure that allows rapid absorption of moisture (Wolf et al., 1952), in addition to being connected to the base of the germ (Domínguez-Pacheco et al., 2010).

\subsection{Nutritional value of corn}

Table 1 shows the results of the proximal analysis of the four varieties of creole corn, observing the highest carbohydrate content in the samples Toro (74.95\%) and Purple-Olotillo (71.29\%). The highest content of carbohydrates, mainly starch is located in the endosperm, which represents $82-84 \%$ of the total weight of the seed (Pérez de la Cerda et al., 2007; Contreras-Jiménez et al., 2013; Serna-Saldivar, 2010); and to a lesser extent in the pericarp, the latter does not represent a significant value and depends on the variety of the corn (Domínguez-Pacheco et al., 2010; Watson, 2003).

The Toro variety had a higher content of Protein (10.61\%), in turn the Purple-Olotillo and Dos-Puntas varieties had the lowest values $(9.02 \%)$, the protein is mainly composed of albumins, globulins and non-protein nitrogen (Singh et al., 2019) finding the 
Table 2. Seed quality and seed anatomy.

\begin{tabular}{|c|c|c|c|c|c|c|c|c|c|}
\hline Variety & $\begin{array}{c}\begin{array}{c}\text { Length } \\
(\mathrm{mm})\end{array} \\
\end{array}$ & $\begin{array}{l}\text { Width } \\
(\mathrm{mm})\end{array}$ & $\begin{array}{l}\text { Thickness } \\
(\mathrm{mm})\end{array}$ & $\begin{array}{c}\mathrm{HW} \\
\left(\mathrm{Kg} \mathrm{hL}^{-1}\right)\end{array}$ & $\begin{array}{c}\text { TKG } \\
(\mathrm{g})\end{array}$ & $\begin{array}{c}\text { Endosperm } \\
(\%)\end{array}$ & $\begin{array}{c}\text { Pericarp } \\
(\%)\end{array}$ & $\begin{array}{c}\text { Pedicel } \\
(\%)\end{array}$ & $\begin{array}{c}\text { Germ } \\
(\%) \\
\end{array}$ \\
\hline Pur & $0.44 \pm 0.06$ & $9.89 \pm 0.0$ & $4.15 \pm 0.07^{\mathrm{b}}$ & $75.73 \pm 3.77^{\mathrm{a}}$ & $111.11 \pm 0$ & $84.25 \pm 0.72^{\mathrm{a}}$ & $4.35 \pm 0.32^{c}$ & $3.61 \pm 0.04^{\mathrm{a}, \mathrm{b}}$ & $7.79 \pm 0.39^{b}$ \\
\hline Dos Puntas & $11.42 \pm$ & $8.68 \pm 0.67^{c}$ & $4.01 \pm 0.09^{b}$ & $77.52 \pm 5.01^{\mathrm{a}}$ & $143.11 \pm 2.04^{\mathrm{a}}$ & $79.65 \pm 1.05^{\mathrm{b}}$ & & $3.78 \pm 0.59^{\mathrm{a}}$ & $10.75 \pm 0.52^{\mathrm{a}}$ \\
\hline Toro & $11.59 \pm 0.54^{\mathrm{b}}$ & $10.79 \pm 0.75^{\mathrm{a}}$ & $7.71 \pm 0.19^{\mathrm{a}}$ & $77.74 \pm 3.08^{\mathrm{a}}$ & $103.56 \pm 2.78^{\mathrm{d}}$ & $84.25 \pm 0.24^{\mathrm{a}}$ & $5.34 \pm 0.30^{\mathrm{b}}$ & $4.01 \pm 0.18^{\mathrm{a}}$ & $6.40 \pm 0.49^{c}$ \\
\hline Olotillo & $12.37 \pm 0.45^{\mathrm{a}}$ & $9.81 \pm 0.11^{\mathrm{b}}$ & $3.99 \pm 0.20^{\mathrm{b}}$ & $79.98 \pm 4.90^{\mathrm{a}}$ & $116.89 \pm 4.29^{b}$ & $84.19 \pm 1.32^{\mathrm{a}}$ & $6.20 \pm 0.41^{\mathrm{a}}$ & $2.41 \pm 0.97^{\mathrm{b}}$ & $7.20 \pm 0.65^{\mathrm{b}, \mathrm{c}}$ \\
\hline
\end{tabular}

Note: ${ }^{\star}$ Different letters in each row indicate significant difference $(\alpha=0.05)$.

Table 3. Color of corn meal.

\begin{tabular}{cccr}
\hline Variety & $\mathrm{L}$ & $\mathrm{a}$ & $\mathrm{b}$ \\
\hline Purple-Olotillo & $61.36 \pm 1.10^{\mathrm{d}^{\star}}$ & $1.20 \pm 0.33^{\mathrm{a}}$ & $1.26 \pm 0.93^{\mathrm{c}}$ \\
Dos Puntas & $73.80 \pm 1.28^{\mathrm{a}}$ & $-3.04 \pm 0.76^{\mathrm{b}}$ & $7.06 \pm 1.75^{\mathrm{b}}$ \\
Toro & $63.94 \pm 1.02^{\mathrm{c}}$ & $-5.10 \pm 0.64^{\mathrm{c}}$ & $14.76 \pm 1.52^{\mathrm{a}}$ \\
Olotillo & $69.34 \pm 1.03^{\mathrm{b}}$ & $-3.62 \pm 0.70^{\mathrm{b}}$ & $8.58 \pm 1.43^{\mathrm{b}}$ \\
\hline Note: ${ }^{\star}$ Different letters in each row indicate significant difference $(\alpha=0.05)$.
\end{tabular}

highest content in the endosperm (74\%) (García-Lara et al., 2019), these proteins being responsible for maintaining the structure of the starches (Serna-Saldivar, 2010), this statement is corroborated with the results obtained, because the Toro variety contains the highest endosperm values $(84.25 \%)$ together with the Morado variety $(84.25 \%)$, the latter has the same endosperm values but low protein, it could be attributed to the amount of protein present in the germ and the endosperm of each variety (Odjo et al., 2018).

In the analyzed samples, no statistical differences were found regarding the lipid content, in grasses the fat content is located in the germ between $76 \%$ to $83 \%, 14 \%$ to $23 \%$ in the endosperm, $1 \%$ to $2 \%$ in the pericarp and $<1 \%$ in pedicel. (Wolf et al., 1952), of which those belonging to the endosperm is more saturated than in the lipids of the germ; endosperm lipids contain higher levels of palmitic, stearic and linolenic acids and lower levels of oleic and linoleic acids (White \& Weber, 2003). It can be said that the bioavailability of these depends many times on the variety and conformation of fatty acids (Odjo et al., 2018).

The fiber content of the four varieties of corn is centered on the varieties Olotillo (13.84\%) and Dos Puntas (11.91\%), it is in the pericarp where the greatest amount of fiber is located, characterized by a high content of crude fiber, which consists mainly of hemicellulose, cellulose and lignin, with hemicellulose being the main source of fiber (Singh et al., 2019), in Table 2, it is shown that the varieties with the highest pericarp content are Olotillo (6.2\%) and Dos Points (5.82\%), as alternative sources of fiber there are the walls of the germ and endosperm, which contain $8.8 \%$ and $2.7 \%$, respectively (Barron et al., 2007).

\subsection{Color of corn flour}

Creole corn flours can be observed in Figure 1, and the color results of the Creole corn flours are presented in Table 3. The brightness value $\left(\mathrm{L}^{*}\right)$ showed significant differences between the flours, being the variety Dos Puntas $(73.80 \pm 1.28)$ the one that registered a higher value with respect to the rest of the flours, that is, they present a whiter and lighter color. With respect to the measurement of $\mathrm{a}^{*}$ (variation from red to green) significant differences were also observed between the flours. The highest value was for the Purple-Olotillo variety $(1.20 \pm 0.33)$, that is, it tends to have a redder coloration, which can be attributed to its high content of anthocyanins. With respect to the value of $b^{*}$ (variation from yellow to blue), the highest value was reported by the Toro variety $(14.76 \pm 1.52)$, this can be attributed to the yellowish hue presented by the grain.

\subsection{Water Absorption Index (WAI) and Water Solubility Index (WSI)}

The WSI is an indirect measure of the amount of starch damaged in the flour (Contreras-Jiménez et al., 2013), being the flour of the variety Dos-Puntas (9.92\%) the one that obtained the highest value of WSI, in terms of WAI value the Olotillo variety obtained the highest values. As reported by Collado \& Corke (2003), regular corn starch is characterized by having granules of a size of 5-25 $\mu \mathrm{m}$ and a percentage of amylose of $26 \%$, amylose is a linear polymer composed of glucopyranose units attached through a-D- (1-4) glycosidic bond (Karim et al., 2000), due to their helical conformation within each helix a hydrophobic environment is formed (Klucinec \& Thompson, 1999).

Table 2 shows that the Toro variety has the lowest WSI but in turn has the second highest value in terms of WAI, authors such as Singh et al. (2003), mention that the size of the granules of starch is of great importance in the absorption of water, this because, in the presence of a large granule, the rupture thereof is lower and thus the leaching of amylose is minimal achieved a higher WAI and a lower WSI, as mentioned above the corn starch granules are considered small and are easy to break thus achieving greater extraction of amylose. In corn grains, the largest starch granules are located on the outside and the small ones are near the central part (Tang et al., 2000), this is explained in Table 2, since the Purple-Olotillo variety is which has a high percentage of endosperm (84.25\%), and is related to a higher WSI and lower WAI, this due to the size of the starch granules present in the flour.

\section{Conclusion}

The variety of Creole corn Toro presented the highest values of carbohydrates and protein, and lower values of lipids, so it is feasible for use in the preparation of corn-based foods with adequate nutritional properties. On the other hand, if the objective is the extraction of lipids, the purple varieties, Dos Puntas and Olotillo, turn out to be more feasible. The Toro variety presented a grain of greater size and weight, so if it is desired to be marketed as whole grain, it is economically more profitable than the other varieties. The flour of the Olotillo variety presented the highest values of WAI, it can confer better technological properties for food processing. 


\section{References}

Agama-Acevedo, E., Juárez-García, E., Evangelista-Lozano, S., RosalesReynoso, O. L., \& Bello-Pérez, L. A. (2013). Características del almidón de maíz y relación con las enzimas de su biosíntesis. Agrociencia, 47(1),1-12.

Agama-Acevedo, E., Ottenhof, M. A., Farhat, I., Paredes López, O., Ortíz Cáceres, J., \& Bello López, L. A. (2004). Efecto de la nixtamalización sobre las características moleculares del almidón de variedades pigmentadas de maíz. Interciencia, 29(11), 643-649.

Aguayo-Rojas, J., Mora-Rochín, S., Cuevas-Rodríguez, E. O., SernaSaldivar, S. O., Gutierrez-Uribe, J. A., Reyes-Moreno, C., \& MilánCarrillo, J. (2012). Phytochemicals and antioxidant capacity of tortillas obtained after lime-cooking extrusion process of whole pigmented Mexican Maize. Plant Foods for Human Nutrition, 67(2), 178-185. http://dx.doi.org/10.1007/s11130-012-0288-y. PMid:22562094.

Aguilar-Castillo, J. A., Carballo-Carballo, A., Castillo-González, F., Santacruz-Várela, A., Mejía-Contreras, J. A., Crossa-Hiriartte, J. \& Baca-Castillo, G. (2006). Diversidad fenotípica y variantes distintivas de la raza Jala de maíz. Agricultura Técnica en México, 32(1), 57-66.

Anderson, R. A., Conway, H. F., Pfeifer, V. F. \& Griffin, L. Jr. (1969). Gelatinization of corn grits by roll-and extrusion-cooking. Cereal Science Today, 14(1), 4-12.

Barron, C., Surget, A., \& Rouau, X. (2007). Relative amounts of tissues in mature wheat (Triticum aestivum L.) grain and their carbohydrate and phenolic acid composition. Journal of Cereal Science, 45(1), 88-96. http://dx.doi.org/10.1016/j.jcs.2006.07.004.

Burak, R., \& Broccoli, A. M. (2004). Effect of genotype x environment interactions in popcorn maize yield and grain quality. Spanish Journal of Agricultural Research, 1, 85-92.

Colín, S. M. (2000). Mejoramiento genético del maíz en la época prehispánica. Agricultura Técnica en México, 1(1), 3-15.

Collado, L. S., \& Corke, H. (2003). Starch properties and functionalities. In G. Kaletunc \& K.J. Breslauer (Eds.), Characterization of cereals and flours (pp. 473-506). New York: Marcel Dekker.

Contreras-Jiménez, B., Morales-Sánchez, E., Reyes-Vega, M. L., \& Gaytán-Martínez, M. (2013). Propiedades funcionales de harinas de maíz nixtamalizado obtenidas por extrusión a baja temperatura. CYTA: Journal of Food, 12(3), 263-270.

Domínguez-Pacheco, A., Aguilar, C. H., Orea, A. C., Carballo, A. C., Bautista, R. Z., \& Ortíz, E. M. (2010). Semilla de maíz bajo la influencia de irradiación de campos electromagnéticos. Revista Fitotecnia Mexicana, 33(2), 183-188.

Fernández-Suárez, R., Morales-Chávez, L. A., \& Gálvez-Mariscal, A. (2013). Importancia de los maíces nativos de México en la dieta nacional: Una revisión indispensable. Revista Fitotecnia Mexicana, 36(3-A), 275-283.

Figueroa-Cárdenas, J. D. D., González, D. E. N., Sánchez, A. M., Taba, S., Martínez, M. G., Medina, J. J. V., Sánchez, F. R., \& Cuevas, F. A. (2013). Propiedades físicas del grano y calidad de los grupos raciales de maíces nativos (criollos) de México. Revista Fitotecnia Mexicana, 36, 305-314.

García-Lara, S., Chuck-Hernández, C., \& Serna-Saldivar, S. O. (2019). Development and structure of the Corn Kernel. In S. O. SernaSaldivar. Corn Chemistry and Technology (3rd ed., pp. 147-163). Sawston, Inited Kingdom: Woodhead Publishing.

Granito, M., \& Guerra, M. (1995). Uso del germen desgrasado de maíz en harinas compuestas para panificación. Archivos Latinoamericanos de Nutricion, 45(4), 322-328. PMid:9161449.
Grossi, G. V. Ohaco Domínguez, E.H., \& De Michelis, A. (2015) Determinación de fibra dietética total, soluble e insoluble en hongos comestibles de cultivo pleurotus ostreatus (p. 32) Bariloche: INTA EEA. Ministerio de Agricultura, Ganadería y Pesca.

Guillén-Pérez, L. A., Sánchez Quintanar, C., \& Domenech, S. M. (2002). Análisis de atribución causal en el uso de semilla criolla y semilla mejorada de maíz. Agrociencia, 36, 377-387.

Guiné, R. P. F., \& Barroca, M. J. (2014). Quantification of browning kinetics and colour change for quince (Cydonia oblonga Mill.) exposed to atmospheric conditions. Agricultural Engineering International: CIGR Journal, 16(4), 285-298.

Hernández-Casillas, J. M., \& Esquivel-Esquivel, G. (2004). Rendimiento de grano y características agronómicas en germoplasma de maíz de valles altos de México. Revista Fitotecnia Mexicana, 27, 27-31.

Karim, A. A., Norziah, M. H., \& Seow, C. C. (2000). Methods for the study of starch retrogradation. Food Chemistry, 71(1), 9-36. http:// dx.doi.org/10.1016/S0308-8146(00)00130-8.

Kato T. A., Mapes, C., Mera, L. M., Serratos, J. A., \& Bye, R. A. (2009). Origen y diversificación del maíz: Una revisión analitica. Universidad Nacional Autónoma de México, Comisión Nacional para el Uso y Conocimiento de la Biodiversidad (p. 116). México: Editorial Impresora Apolo.

Klucinec, J. D., \& Thompson, D. B. (1999). Amylose and amylopectin interact in retrogradation of dispersed high-amylose starches. Cereal Chemistry, 76(2), 282-291. http://dx.doi.org/10.1094/ CCHEM.1999.76.2.282.

López, C. G., Eyherabide, G. H., Delucchi, C., Percibaldi, N. M., Castellarín, J., Pedrol, H., \& Borrás, F. (2005, Noviembre 16-18). Selección de poblaciones locales de maíz como fuente de alelos favorables para el mejoramiento del peso hectolítrico y la relación de molienda en un híbrido flint $\mathrm{x}$ dentado. In VIII Congreso Nacional de Maíz. Rosario, Santa Fe.

Magdaleno-Hernández, E., Mejía-Contreras, A., Martínez-Saldaña, T., Jiménez-Velázquez, M. A., Sánchez-Escudero, J., \& García-Cué, J. L. (2016). 2016 Selección tradicional de semilla de maíz criollo. Agricultura, Sociedad y Desarrollo, 13(3), 437-447.

Mauricio-Sánchez, R. A., Figueroa Cárdenas, J. D., Taba, S., Reyes Vega, M. L., Rincón Sánchez, F., \& Mendoza Galván, A. (2004). Caracterización de accesiones de maíz por calidad de grano y tortilla. Revista Fitotecnia Mexicana, 27(3), 213-222.

Montgomery, D. C. (2017). Design and analysis of experiments. New York: John Wiley \& Sons.

Muñoz-Hernández, R. A., Calderón, A., Cruz-Orea, A., Sánchez Sinencio, F., Tomas, S. A., \& González de la Cruz, G. (1999). Estudio de la influencia del $\mathrm{Ca}(\mathrm{OH})^{2}$ en las películas de pericarpio de maíz nixtamalizado mediante técnicas fototérmicas. Superficies y Vacío, 8, 80-84.

Navarro-Garza, H., Hernández-Flores, M., Castillo-González, F., \& Pérez-Olvera, A. (2012). Diversidad y caracterización de maíces criollos: Estudio de caso en sistemas de cultivo en la Costa Chica de Guerrero, México. Agricultura, Sociedad y Desarrollo, 9(2), 149-165.

Odjo, S., Béra, F., Beckers, Y., Foucart, G., \& Malumba, P. (2018). Influence of variety, harvesting date and drying temperature on the composition and the in vitro digestibility of corn grain. Journal of Cereal Science, 79, 218-225. http://dx.doi.org/10.1016/j.jcs.2017.10.008.

Paredes López, O., Guevara Lara, F., \& Bello Pérez, L. A. (2009). La nixtamalización y el valor nutritivo del maíz. Ciencias, 92(92), 60-70.

Pérez de la Cerda, F. D. J., Carballo-Carballo, A., Santacruz-Varela, A., Hernández-Livera, A. \& Molina-Moreno, J. C. (2007). Calidad 
fisiológica en semillas de maíz con diferencias estructurales. Agricultura Técnica en México, 33(1), 53-61.

Pérez-Mendoza, C., Livera, A. H., Cossio, F. V. G., Santos, G. G., Carballo, A. C., Rojas, T. R. V. \& Gómez, M. R. T. (2006). Tamaño de semilla y relación con su calidad fisiológica en variedades de maíz para forraje. Agricultura Técnica en México, 32(3), 341-352.

Revilla, P., Landa, A., Rodríguez, V. M., Romay, M. C., Ordás, A., \& Malvar, R. A. (2008). Maize for bread under organic agriculture. Spanish Journal of Agricultural Research, 6(2), 241-247. http://dx.doi. org/10.5424/sjar/2008062-315.

Salinas-Moreno, Y., \& Aguilar-Modesto, L. (2010). Efecto de la dureza del grano de maíz (Zea mays L.) sobre el rendimiento y calidad de la tortilla. Ingeniería Agrícola y Biosistemas, 2(1), 5-11. http://dx.doi. org/10.5154/r.inagbi.2010.08.009.

Serna-Saldivar, S. O., \& Carrillo, E. P. (2019). Food uses of whole corn and dry-milled fractions. In S. O. Serna Saldívar. Corn: chemistry and technology (3rd ed., pp. 453-467). Duxford, United Kingdom: Woodhead Publishing.

Serna-Saldivar, S. O. (2010). Physical properties, grading and specialty grains. In S. O. Serna Saldívar. Cereal Grains: properties, processing and nutritional attributes (pp. 43-81). Boca Raton: CRC Press.

Singh, N., Singh, J., Kaur, L., Singh Sodhi, N., \& Singh Gill, B. (2003). Review: Morphological, thermal and rheological properties of starches from different botanical sources. Food Chemistry, 81(2), 219-231. http://dx.doi.org/10.1016/S0308-8146(02)00416-8.

Singh, N., Singh, S., \& Shevkani, K. (2019). Maize: Composition, bioactive constituents, and unleavened bread. In V. R. Preedy, R. R. Watson \& V. B. Patel. Flour and breads and their fortification in health and disease prevention (pp. 111-121). London: Academic Press.
Sistema de Información Agroalimentaria y Pesquera-SIAP (2018). Atlas Agroalimentario 2012-2018 (p. 102-104). México: SIAP.

Tang, H., Ando, H., Watanabe, K., Takeda, Y., \& Mitsunaga, T. (2000). Some physicochemical properties of small-, medium-, and largegranule starches in fractions of waxy barley grain. Cereal Chemistry, 77(1), 27-31. http://dx.doi.org/10.1094/CCHEM.2000.77.1.27.

Turrent-Fernández, A., Wise, T. A., \& Garvey, E. (2012). Factibilidad de alcanzar el potencial productivo de maíz de México (p. 24). Washington, DC: Wilson Center, Report.

Valenzuela-Lagarda, J. L., Gutiérrez-Dorado, R., Pacheco-Aguilar, R., Lugo-Sánchez, M. E., Valdez-Torres, J. B., Reyes-Moreno, C., Mazorra-Manzano, M. A., \& Muy-Rangel, M. D. (2017). Botanas expandidas a base de mezclas de harinas de calamar, maíz y papa: efecto de las variables del proceso sobre propiedades fisicoquímicas. CYTA: Journal of Food, 15(1), 118-124. http://dx.doi.org/10.1080/ 19476337.2016.1219391.

Watson, S. A. (2003). Description, development, structure, and composition of the corn kernel. In P. J. White, \& L. A. Johnson (Eds.), Corn chemistry and technology (Vol. 2, pp. 69-106). St. Paul: American Association of Cereal Chemists Inc.

Wellhausen, E. J., Roberts, L. M., \& Hernández-Xolocotzi, E. (1951). Razas de Maíz en México: Su origen, características y distribución (p. 237, Folleto Técnico, 5). México, DF: Oficina de Estudios Especiales, Secretaría de Agricultura y Ganadería.

White, P. J., \& Weber, E. J. (2003). Lipids of the kernel. In P. J. White, \& L. A. Johnson (Eds.), Corn Chemistry and Technology (Vol. 2, pp. 355-405). St Paul: American Association of Cereal Chemists, Inc.

Wolf, M. J., Buzan, C. L., Macmasters, M. M., \& Rist, C. E. (1952). Structure of the mature corn kernel. I. Gross anatomy and structural relationships. Cereal Chemistry, 29(5), 321-333. 